\title{
Study on Chinese-English Translation of Yunnan Ethnic Cultural Classics in Multicultural Contexts
}

\author{
Yanchun Zhang \\ Department of Foreign Languages \\ The Engineering \& Technical College of Chengdu University of Technology \\ Leshan, Sichuan, China \\ 110711124@qq.com
}

Keywords: multicultural contexts, ethnic cultural classics, Chinese-English translation, Yunan

\begin{abstract}
With the integration of world culture, global culture and cultural diversity is the common heritage of mankind. In the multicultural contexts, translation is shouldering mission of promoting national exchanges and cultural diversity and strengthening the construction of world peace culture. This paper, from the multicultural perspective, gives an analysis of the current situation of translation for the ethnical cultural classics of Yunan, China. It explores the subject and the translating method for the ethnical cultural classics to better publicize and promote the ethnical cultural classics of Yunnan hoping more international scholars come to explore the mysterious and colorful cultures of all ethnic groups in Yunan.
\end{abstract}

\section{Introduction}

As is proposed by a Chinese professor Hongyin Wang in his book, "A wealth of cultural classics has been handed down in the history of world civilization. The translation and dissemination of these documents is the main way for human civilization transmission. Therefore the translation of Chinese ethnic cultural classics is not only a kind of important translation activities but also a special field in translation studies. Meanwhile it is an important approach for China to go into the outside world to achieve culture exchange as well as culture fusion both in home and abroad". (trans by the author )[1] Globalization has become an irreversible trend and reality of the development of the times, the world cultural exchange must be accompanied by the cultural translation. As an important symbol of Chinese national culture, Chinese cultural classics bear the essence of Chinese culture. The of Chinese ethnic cultural classics into English can be a reconstruction of the culture image promoting national cultural self-confidence, arousing the global Chinese cultural consciousness and cultural identity. It becomes a new topic and a mission for translators.

Under the background of globalization and multiculturalism, the cultural exchanges between China and the West are becoming more and more frequent. The protection, publicity and translation of non-material cultural heritage of various ethnic groups are becoming more and more urgent. Chinese translator, Xianyi Yang, said, "translation is a tool to communicate with people who speak different languages. Human thoughts and feelings can be exchanged for people from different regions or countries. In this sense, everything should be translatable." (trans by the author ) It is the same translation of Chinese ethnic classics. It is reasonable to say that " the nation is the world, the culture is the classics, and only classics is eternal". The so-called "only nation is the world" is based on the maintenance of the national characters. The second is the translation into the world, for there is no "translation", there is no universal. Therefore, it is translators' responsibility to have the Chinese ethnic classics translated into the most widely used language, English, so that readers can better understand Chinese ethnic cultural classics on a global scale and make it popularized.

\section{Research Background}

Yunnan, with more than 25 minority groups living, has rich and valuable cultural resources of ethnic minorities. A series of on Yunnan culture books of ethnic groups in Chinese has been 
published and released but with fewer English versions, which hinders the introduction of ethnic minority's culture in Yunan Province to the world to a certain extent. Therefore, a study on the Translation of ethnic classics of Yunnan Province into English from the Perspective of Multiculturalism has far-reaching influence. The publication of the series of Yunnan ethnic cultural knowledge has been loved and obsessed by the majority of readers. In order to make the world a better understanding of the various customs of ethnic groups in Yunnan, to promote the Yunnan culture, overcome barriers in cultural exchange caused by language. The need for more scholars and translators' participation in the translation of books in this field becomes urgent in the hope of introducing and recommending the material civilization and spiritual civilization of Yunnan including the food, clothing, housing, production, language, literature, science, art, philosophy, religion, customs, festivals and other cultural traditions of the ethnic group.

\section{Multiculturalism and Multicultural Contexts}

"Multiculturalism" . "Multiculturalism is a term used in both sociology and political philosophy. It is an ambiguous term: it can mean a cultural pluralism in which the various ethnic groups collaborate and dialog with one another without having to sacrifice their particular identities. In sociology and everyday usage it is a synonym for pluralism with the two terms often used interchangeably and refers to either specific mixed ethnic community areas where multiple cultural traditions exist or a single country within which they do. Groups associated with an aboriginal ethnic group and foreigner ethnic groups are most often the focus." [2]

Multiculturalism in Yunnan Ethnic Cultural Classics . National culture is the culture that has been created and developed in the course of historical development for all nations. It includes material culture and spiritual culture. (trans by the author )[3] Multiculturalism is an important resource of a nation or country, which can benefit future generations. For the Yunnan ethnic cultural classics, it draws attention for scholars or people who take deep interest in the ethnical minority group's cultures. It consists of the cultures of Dai people living in Xishuangnan or Dehong Autonomous Prefecture, Bai people in Dali, Naxi people in Lijiang, Yi people in Chuxiong, Tibetans in Diqing and so on. Yunan is a land with multicultural contexts. The diversities of cultures may bring shocks and conflicts; nonetheless ethnic cultural classics are worthy of exploring and stdudying, which would benefit the prosperity and development for all the nations in the world to join together.

\section{The Best Subject for Translation of Yunnan Ethnic Cultural Classics}

Loud cheers for translation of ethnic cultural classics carry forward the essence of Chinese culture, and let the world know more about broad and profound cultures in China. It has become the young translators' inescapable historical mission. The subject of the translation of the ethnic culture classics should be, and must be native scholars and translators in China. For, in these classics, it involves different cultures such as the Han people culture, the Dai culture or other cultures of all the 26 ethnic minorities in Yunan.

Chinese Translators are the Best Subjects . Chinese translator is the best English translation of the main ethnic cultural classics, mainly because: first, native language scholars and translators of China grow up in Chinese culture. They can read between the lines with a good command of Chinese and understand Chinese culture from semantic, vocabulary and cultural aspects. Only by accurately understanding the meaning of the original can we express it correctly and in English. Secondly, on the principle of $\mathrm{Fu}$ Yan, a famous theorist in translation, who "formulated the three characters (faithfulness, expressiveness and elegance) in his Introductory Remarks to his translation, Evolution and Ethics, are thought of and supported as the one and only maxim all translators must observe."[4] Faithfulness should be given the priority in translation. That is to say, for the purpose of transferring and spreading the essence of Chinese diversified cultures, translators have the ability of accurate translation in terms of culture. So Chinese authorities should be responsible for the encouragement of native Chinese translators to get involved in the translation project or work with 
financial and material support. Only in this way, can the work be a systematically organized one from objectively from multicultural perspective.

Disadvantages of Western Translators Being the Subject. Firstly, due to the influence of "native culture centrism" among western translators, in the course of translating ethnic classic of China they mostly adopted domestication strategy to target readers. In the process of translation, cultural mistranslation or misinterpretation is quite common. Secondly, the translator is very easy to be influenced by their own culture, some of the cultural loaded words are selectively removed or ignored, resulting in cultural understanding and misunderstanding, thus making the impartial and comprehensive translation. "Moreover, western translators are basically working alone, lacking of systematical organization. They translate according to their own preferences and interests. Translation works are difficult to represent all fields of Chinese national culture. (trans by the author)"'[5]

Qualities for Translators of Ethnic Cultural Classics. Qualities for translating the ethnic classics are a master of translations theories, a good command of Chinese and English, a profound knowledge in multicultural contexts, a local language of a certain ethnic group in Yunan, China, a rigid and strict attitude towards translation and a deep interest in the cultures of ethnic groups. It is essential to be a translator in multicultural contexts.

\section{Translation methods}

Foreignation or Domestication . "In the translation of Yunnan ethnic cultural classics into English, translators mainly adopt the foreignizing translation strategy, which focuses on the orientation of source language, and with domestication translation strategy as a supplement. As Minrong Zhang pointed out that "when Chinese classics are translated into English, translators should be under the guidance of cultural translation view and adopt the strategy of foreignization, with the proper use of the China English for expanding readers' vision and promoting cultural exchanges and multicultural development". (trans by the author )[6]Translation should be faithful to the content of the original text, especially the ethnic culture of the original. In this kind of translation, it involves the Chinese Han culture, cultures of the 26 ethnic groups and culture of English speaking countries. In such multicultural contexts, it is a difficult and challenging task to translate or transfer among the three cultures. For in the Yunnan Ethnic Cultural Classics Series, a large number of culture loaded words are included. There are huge gaps between three cultures. It is very difficult to find the corresponding words in English, so translators need to be flexible in translation strategies for the sake of the reproductions of information in source language to the greatest degree.

Translation methods. In author's participation of translating the two Chinese-English translation works of Yunnan ethnic groups in China, "Ceremonies for the Deceased-Funerals of Ethnic Groups of Yunnan and Essays Commemorating Mr. Gao Lishi's Sixty-year Engagement in Dai Studies", the following translation methods are adopted. In this paper, from the perspective of multicultural contexts, the author explores the Chinese-English translation patterns and translation strategies of the ethnic groups ethnical cultural classics with foreignizing translation and domesticating translation as criteria. In brief, phonetic transliteration, literal translation, substitution, interpretation, basic meaning, cultural equivalence in semantic style and other aspects of analysis are adopted. The author summarizes translation methods used in the work and they are shown in the following table: 
Table 1

\begin{tabular}{|c|c|c|}
\hline Chinese Version & English Translation & Translation Method \\
\hline 指路经[7] & $\begin{array}{l}\text { Scripture of Guiding the Souls for Souls } \\
\text { of the Deceased }\end{array}$ & literal translation , addition \\
\hline 苦养粑粑[7] & $\begin{array}{l}\text { Tartary buckwheat baba (a kind of local } \\
\text { snack made of buckwheat) }\end{array}$ & transliteration , annotation \\
\hline 祭司“毕摩” [7] & the priest "Bimo" & literal translation, free translation \\
\hline “董萨”[7] & the priest "Dongsa" & transliteration , addition \\
\hline $\begin{array}{c}\text { 祖源故地“赛入 } \\
\text { 山” [7] }\end{array}$ & $\begin{array}{l}\text { "Sairu Mountain" which is the land of } \\
\text { their ancestors' origin }\end{array}$ & transliteration ,literal translation \\
\hline $\begin{array}{l}\text { 一个叫“阿细默 } \\
\text { 默”的地方[7] }\end{array}$ & a place named "Aximomo" & transliteration \\
\hline 移民屯田[7] & $\begin{array}{l}\text { the large-scale immigration and garrison } \\
\text { reclamation system (i.e., garrison troops } \\
\text { or peasants open up wasteland and grow } \\
\text { food grain); }\end{array}$ & free translation , annotation \\
\hline 闹丧[7] & clamorous funeral & free translation \\
\hline 闹酒[7] & drink and raise clamor & free translation \\
\hline 佛法僧三宝[8] & $\begin{array}{l}\text { the triple gem: the Buddha, the Dharma } \\
\text { (his teachings), and the Sangha (his } \\
\text { disciples) }\end{array}$ & literal translation ,addition, annotation \\
\hline 傣文[8] & $\begin{array}{l}\text { Daiwen (Dai people's language and } \\
\text { script) }\end{array}$ & transliteration , annotation \\
\hline 傣讷(旱傣) [8] & $\begin{array}{l}\text { "Daine"(the dry Dai: a branch of the } \\
\text { Dai people who mainly used to live in } \\
\text { areas far away from water source) }\end{array}$ & $\begin{array}{lll}\text { addition, } & \text { literal } & \text { translation } \\
\text { transliteration } & \text {,annotation } & \end{array}$ \\
\hline 傣泑(水傣) [8] & $\begin{array}{l}\text { the "Daile" (the water Dai: it also } \\
\text { means the son of water who lives near } \\
\text { the rivers in Yunnan); }\end{array}$ & $\begin{array}{l}\text { Addition, literal translation } \\
\text { transliteration, annotation }\end{array}$ \\
\hline $\begin{array}{l}\text { 傣族称水土为“南 } \\
\text { 领”, “南”为水, } \\
\text { “领”为土地, “南 } \\
\text { 岭”即水土[8] }\end{array}$ & $\begin{array}{l}\text { The Dai people called soil and land as } \\
\text { "Nanling" with the meaning of soil and } \\
\text { land, the Chinese "Nan" refers to water } \\
\text { while the "Ling" refers to soil }\end{array}$ & $\begin{array}{l}\text { literal translation transliteration, } \\
\text { annotation, free translation }\end{array}$ \\
\hline
\end{tabular}

\section{Conclusion:}

The Yunnan ethnic cultural classics, as a treasure of the Chinese nation, the study of English translation of these cultural classics needs more scholars, translators and people who are interested in national culture to participate in the Chinese-English translation on the principle of promoting and publicizing multicultural standard. With more classics translated into English, it can overcome language barriers to spread the unique cultures of ethnic groups in Yunan. It can not only improve the author's academic reputation of the original works but also encourage more scholars or people to 
come to Yunnan, China to participate in cultural studies in a multicultural contexts in the hope of promoting intercultural communication.

Acknowledgements: This research was financially supported by the Fundamental Research Funds for the Engineering \& Technical College of Chengdu University (Grant NO.C112017010)

\section{References:}

[1] Hongyin Wang, "Chinese Masterpiece of English Translation," Foreign Language Teaching and Research Press, 2009. (in Chinese)

[2] Information on https://en.wikipedia.org/wiki/Multiculturalism

[3] Information on https://baike.so.com/doc/857902-907039.html (in Chinese)

[4] Zhongde Liu, "Ten Lectures on Literary Translation," China Translation and Publishing Co.2003. (in Chinese)

[5] Yuehong Huo, "Translation of the Classics: Importance, Subject and Strategy, "Foreign Languages and Their Teaching, vol (9).2005, pp.52-55. ( in Chinese)

[6] Mingrong Zhang, "Study on the Foreignization Strategy of the Translation of the Classics," Journal of Wuzhou University, $\operatorname{Vol}(20) .2010(5), p p .67-70$. ( in Chinese)

[7] Shaoying He, "Ceremonies for the Deceased-Funerals of Ethnic Groups of Yunnan," Yunan Education Press.2000. (in Chinese)

[8] Peng Zheng edit, Yong Hong trans, "Essays Commemorating Mr. Gao Lishi's Sixty-year Engagement in Dai Studies," Yunnan Nationalities Press, 2013. (in Chinese) 